\title{
SIFAT KIMIA SELAI BUAH NAGA, KOMPOSISI MIKROFLORA DAN PROFIL SCFA FESES RELAWAN
}

\author{
[Chemical Properties of Drugon Fruit Jam, Microflora Composition and \\ SCFA Profile of Human Volunteer Faecal]
}

\author{
Nurhayati*, Gama Kusuma, dan Maryanto \\ Jurusan Teknologi Hasil Pertanian, Fakultas Teknologi Pertanian, Universitas Jember, Jember
}

Diterima 16 Maret 2015 / Disetujui 16 Desember 2015

\begin{abstract}
Dragon fruit contains oligosaccharides, Including prebiotic ingredients, that are namely raffinose, stachyose, and fructo-oligosaccharides. The heat treatment process like jam producing can affect the functional properties of a food material. The aim of the research wereto know the effect of jam processing on chemical properties, and their prebiotic properties. Evaluation of the prebiotic properties was conducted by in vivo method i.e. probiotic and enterob acteria population of volunteers faecal (microflora composition), prebiotic index (PI) value and Short Chain Fatty Acid (SCFA) profile. The result showed that the processing of dragon fruit into jams decreased water content, $\beta$-sianin and dissolved particles but increased the Insoluble Indigestible Fraction (IIF). The PI value of dragon fruit jam were 1.70 for white dragon jam and 1.18 for red dragon fruit. The jam processing decreased PI value up to 0.49 (red dragon fruit jam) and 0.54 (white dragon fruit jam). The fresh dragon fruit and the jam produced short chain fatty acid (SCFA) i.e. acetic and propionic acid. It can be concluded that prebiotic properties of white dragon fruit better than red dragon fruit.
\end{abstract}

Keywords: oligosaccharide, prebiotic index (PI), SCFA, probiotic

\begin{abstract}
ABSTRAK
Buah naga mengandung oligosakarida seperti raffinosa, stakiosa, dan frukto-oligosakarida yang merupakan ingredien prebiotik. Proses perlakuan panas seperti pembuatan selai dapat mempengaruhi sifat-sifat fungsional suatu bahan pangan. Tujuan penelitian ini adalah mengetahui perubahan fisik dan kimia akibat pengolahan buah naga menjadi selai serta mengevaluasi sifat-sifat prebiotiknya. Evaluasi sifat-sifat prebiotik tersebut dilakukan secara in vivo yang meliputi populasi probiotik dan enterobakteria feses relawan yang mengonsumsi buah naga segar dan selainya, nilai indeks prebiotik (IP) dan profil asam lemak rantai pendek. Hasil penelitian menunjukkan bahwa pengolahan buah naga menjadi selai mampu menurunkan kadar air, kadar $\beta$-sianin dan jumlah partikel terlarut, tetapi meningkatkan fraksi tidak terlarut dan tidak tercerna Insoluble Indigestible Fraction (IIF). Nilai IP buah naga putih sebesar 1,7 sedangkan nilai IP buah naga merah sebesar 1,18. Proses pengolahan buah naga menjadi selai menurunkan nilai IP hingga 0,49 (selai buah naga merah) dan 0,54 (selai buah naga putih). Buah naga merah dan selainya mampu menghasilkan asam lemak rantai pendek pada feses relawan yang mengonsumsinya yaitu asam asetat dan asam propionat. Hal ini dapat disimpulkan bahwa sifat-sifat prebiotik buah naga putih lebih baik daripada buah naga merah.
\end{abstract}

Kata kunci: buah naga, oligosakarida, indek prebiotik (IP), SCFA, probiotik

\section{PENDAHULUAN}

Buah naga adalah buah dari beberapa jenis kaktus dari marga Hylocereus dan Selenicereus. Terdapat empat varietas buah naga yang umum dikenal masyarakat yaitu: Hylocereus undatus, memiliki kulit buah berwarna merah dengan daging buah putih; Hylocereus polyrhizus, memiliki kulit buah berwarna merah muda dengan daging buah merah; Selenicereus megalanthus dengan kulit buah kuning dan daging buah putih; Hylocereus costaricensis buah naga daging super merah (Rohin et al., 2014; Nurhayati et al., 2014 ${ }^{\mathrm{a}}$ ).

${ }^{*}$ Penulis Korespondensi:

E-mail: nurhayatiftp@yahoo.com 
Buah naga telah dilaporkan mengandung $\beta$ karoten, likopen, dan vitamin $E$, berturut-turut 1,4; 3,4 ; dan $0,26 \mu \mathrm{g} / 100 \mathrm{~g}$ dari bagian yang dapat dimakan (Charoensiri et al., 2009). Biji buah naga mengandung 50\% asam lemak esensial, diantaranya terdiri atas $48 \%$ asam linoleat (C18:2) dan 1,5\% asam linolenat (C18:3) (Ariffin et al., 2009). Oleh karena itu, buah naga memiliki potensi sebagai sumber bahan pangan fungsional untuk memberikan nutrisi yang dapat mencegah penyakit yang berhubungan dengan gizi dan meningkatkan kesehatan fisik konsumen. Selain itu, buah naga juga mengandung oligosakarida. Rohin et al. (2014) melaporkan bahwa komposisi oligosakarida yang meliputi rafinosa, stakiosa dan frukto-oligosakarida menunjukkan berbeda nyata pada taraf uji $P<0,05$ antara buah naga putih dengan buah naga merah. Kadar rafinosa, stakiosa dan frukto-oligosakarida buah naga putih lebih kecil yaitu berturut-turut $204,23 \mu g ; 100 \mathrm{~g} ; 249,43 \mu \mathrm{g} / 100 \mathrm{~g}$ dan 14,92 $\mu \mathrm{g} / 100 \mathrm{~g}$ daripada buah naga merah $324,57 \mu \mathrm{g} / \mathrm{g}$; $283,58 \mu \mathrm{g} / 100 \mathrm{~g}$ dan 29,22 $\mu \mathrm{g} / 100 \mathrm{~g}$. Oligosakarida buah naga menunjukan sifat prebiotik yang termasuk didalamnya ketahanan terhadap kondisi asam pada perut manusia, ketahanan sebagian terhadap a-amilase manusia dan kemampuan untuk merangsang pertumbuhan Lactobacillus dan Bifidobacteria. Oleh karena itu, buah naga sumber potensial dari prebiotik yang bisa digunakan sebagai ingredien dalam pangan fungsional dan produk nutraceutical (Wichienchot et al., 2010).

Stintzing et al. (2003) melaporkan bahwa buah naga merah mengandung pigmen $\beta$-sianin yang bersama-sama dengan dan $\beta$-xanthins dikelompokkan sebagai $\beta$-lain. Senyawa tersebut merupakan pigmen larut dalam air yang mengandung nitrogen, yang disintesis dari asam amino tirosin menjadi dua kelompok struktural. Beta-lain yang tergolong $\beta$ sianin berwarna merah-violet, sedangkan $\beta$-xanthins berwarna kuning-oranye. Pietrzkowski et al. (2014) menjelaskan bahwa variasi konjugasi pada $\beta$-nidin aglikon maupun cyclo-DOPA baik dalam bentuk glikosida maupun asilglikosida menghasilkan berbagai tipe $\beta$-sianin. Beta-sianin merupakan struktur asam $\beta$-lamic yang berikatan dengan residu cyclo3,4-dihydroxypheny-lalanine (cyclo-DOPA) hasil dari sintesis asam amino tirosin. Semua $\beta$-sianin membutuhkan asam amino tirosin yang disintesis menjadi residu cyclo-DOPA. Beta-sianin yang berwarna merah-violet merupakan hasil kondensasi asam $\beta$-lamic dengan cyclo-DOPA menjadi $\beta$-nidin aglycon yang merupakan bentuk umum $\beta$-sianin secara alami, sedangkan $\beta$-xantin terbentuk dari kon-densasi dari senyawa asam amino dengan asam $\beta$-lamic.

Berdasarkan struktur kimianya, $\beta$-sianin dikelompokkan menjadi empat yaitu, grup $\beta$-nin, amaranthine, gomphrenin dan 2-Descarboxy- $\beta-n i n$.
Warna pada $\beta$-sianin merupakan hasil absorbansi maksimum ( $\left.\lambda_{\max } 534-554 \mathrm{~nm}\right)$. Stabilitas $\beta$-sianin dipengaruhi oleh $\mathrm{pH}$, cahaya, panas dan oksigen (Mastuti, 2010). Buah yang diolah menjadi selai memiliki kelebihan seperti umur simpannya yang bisa mencapai berbulan-bulan. Selain itu, selai buah naga dapat pula diformulasikan sebagai prebiotik pada produk kombinasi prebiotik dan probiotik (sinbiotik). Desnilasari dan Lestari (2014) menyebutkan bahwa penggunaan selai pisang ambon sebagai prebiotik serta $L$. casei sebagai probiotik dapat menghasilkan produk minuman sinbiotik.

Pada umumnya buah naga dikonsumsi dalam bentuk buah segar sehingga memiliki kelemahan tidak tersedianya buah naga bila sedang tidak musim. Oleh karena itu, buah naga perlu diolah untuk menjamin ketersediaannya ketika tidak sedang musim, karena dengan pengolahan, buah naga akan memiliki umur simpan yang lebih panjang. Buah naga dapat diolah lebih lanjut, salah satunya dalam bentuk selai buah naga. Menurut Arie et al. (2010) selai buah tahan disimpan sampai berbulan-bulan. Di samping akibat penambahan gula sebagai bahan humektan juga akibat terjadinya evaporasi/penguapan air yang menurunkan kandungan air $\left(a_{w}\right)$. Proses pembuatan selai dilakukan dengan memanaskan bubur buah naga. Pengolahan buah naga menjadi selai diduga dapat mempengaruhi potensi prebiotik (raffinosa, stakiosa dan frukto-oligosakarida) buah naga. Penelitian ini bertujuan untuk mengetahui pengaruh pengolahan terhadap sifat-sifat prebiotik selai buah naga dari varietas Hylocereus undatus (buah naga putih) dan Hylocereus polyrhizus (buah naga merah).

\section{BAHAN DAN METODE}

\section{Bahan}

Bahan utama yang digunakan dalam penelitian ini yaitu buah naga merah dan buah naga putih yang diperoleh dari petani buah naga di Banyuwangi, Jawa Timur. Buah naga dipanen pada umur 55 hari setelah bunga mekar.

\section{Metode}

Penelitian dilakukan dalam tiga tahap yaitu: tahap pembuatan selai buah naga yang mengacu pada teknologi selai (Arie et al., 2010) yang dimodifikasi tanpa penambahan gula, dan tahap analisis kadar air, kadar Insoluble Indigistible Fractions (IIF), jumlah pigmen $\beta$-sianin, jumlah partikel terlarut air, serta tahap evaluasi sifat-sifat prebiotik secara in vivo berdasarkan profil mikroflora feses relawan dan Short Chain Fatty Acid (SCFA) buah naga merah dan putih segar serta produk selainya. 


\section{Pembuatan selai buah naga}

Tahap pembuatan selai ini dilakukan dengan mengupas dan menimbang buah naga merah atau putih sebanyak $1 \mathrm{~kg}$ kemudian diparut. Selanjutnya dipanaskan selama 50 menit sampai mengental dan terbentuk selai buah naga. Selama proses pembuatan selai buah naga tidak dilakukan penambahan gula maupun asam sitrat. Hal ini dikarenakan buah naga sudah manis dan berasa asam sehingga tanpa penambahan kedua bahan tersebut sudah menghasilkan produk selai yang berasa manis dan asam. Selain itu juga meminimalkan interaksi bahan tambahan pangan (food additives) sehingga meminimalkan kesalahan evaluasi sifat-sifat prebiotik secara in vivo. Tahap kedua dilakukan analisis sifat kimia yaitu perubahan kadar $\beta$-sianin, partikel terlarut serta evaluasi sifat-sifat prebiotik secara in vivo. Analisis kadar air dilakukan dengan menggunakan metode pengeringan oven (AOAC, 2005).

\section{Analisis perubahan kadar $\beta$-sianin (Stintzing et al., 2003)}

Analisis perubahan kadar B-sianin dilakukan dengan menimbang $1 \mathrm{~g}$ sampel buah naga merah segar atau $0,52 \mathrm{~g}$ sampel selai buah naga merah, ditera $10 \mathrm{~mL}$ menggunakan bufer fosfat $\mathrm{pH} 6,5$ (Merck, Germany) atau aquades yang kemudian di ambil $1 \mathrm{~mL}$ dan ditera hingga tanda batas $10 \mathrm{~mL}$. Kemudian divortex selama 10 detik. Larutan sampel diukur absorbansinya dengan menggunakan spektrofotometer (GENESYS 10S UV-Vis, USA) pada panjang gelombang $550 \mathrm{~nm}$.

\section{Analisis jumlah partikel terlarut (Stintzing et al., 2003)}

Analisis jumlah partikel terlarut dilakukan dengan menimbang $45 \mathrm{~g}$ sampel buah naga putih atau selainya. Sebanyak $45 \mathrm{~g}$ sampel selai buah naga putih kemudian ditera dengan $10 \mathrm{~mL}$ aquades. Kemudian divortex selama 10 detik. Larutan sampel diukur absorbansinya dengan menggunakan alat spektrofotometer pada panjang gelombang $450 \mathrm{~nm}$.

\section{Analisis kadar serat tidak larut air Insoluble Indigestible Fraction (IIF)}

Analisis kadar IIF dilakukan dengan menggunakan metode enzimatis yang dikombinasi dengan metode gravimetri (Nurhayati, 2011; Nurhayati et al., 2014 ${ }^{\mathrm{D}}$ ). Sebanyak $0,2 \mathrm{~g}$ produk selai buah naga merah dan putih ditambah $4 \mathrm{~mL}$ buffer asetat (Merck, Germany) kemudian dididihkan dalam penangas air selama 30 menit. Sampel didinginkan dan ditambah $1 \mathrm{~mL}$ larutan enzim yang mengandung enzim pankreatin (Sigma, Cat. No. P7545, USA) dan amiloglukosidase (Sigma, Cat. No. A7095, Denmark). Selanjutnya sampel diinkubasi pada suhu $37^{\circ} \mathrm{C}$ selama 120 menit dan disaring. Penentuan kadar IIF diperoleh dari residu penyaringan, kemudian sampel dicuci dengan $5 \times 1$ $\mathrm{mL}$ aquades, $5 \times 1 \mathrm{~mL}$ etanol $97 \%$ dan $5 \times 1 \mathrm{ml}$ aseton (CV. Makmur Sejati), selanjutnya dikeringkan pada suhu $50^{\circ} \mathrm{C}$ dengan menggunakan pengering oven (Memmert, Frankfurt, Germany) sampai berat konstan (sekitar 12 jam) dan ditimbang setelah didinginkan dalam desikator (D2). Kadar IIF dihitung dengan rumus sebagai berikut:

$$
\text { Kadar IIF }(\%)=\frac{D 2-D 1}{W} \times 100 \%
$$

Keterangan :

$\mathrm{W}=$ berat sampel $(\mathrm{g})$

$\mathrm{D} 1$ = berat kertas saring $(\mathrm{g})$

$\mathrm{D} 2$ = berat setelah dianalisis dan dikeringkan $(\mathrm{g})$

\section{Evaluasi sifat-sifat prebiotik secara in vivo}

Evaluasi sifat-sifat prebiotik secara in vivo dilakukan untuk mengetahui profil mikroflora feses relawan dan profil asam lemak rantai pendek (SCFA). Uji sifat-sifat prebiotik secara in vivo dilakukan setelah mendapat persetujuan etik. Penelitian ini telah mendapatkan persetujuan etik dari Fakultas Kedokteran Universitas Jember dengan No. 529/H25.1.11/KE/2014. Kriteria inklusif dan eksklusif mengacu pada penelitian Gullon et al. (2011) yang menggunakan dua relawan manusia untuk uji prebiotik secara in vivo. Relawan yang digunakan dalam penelitian ini memiliki kriteria inklusif yaitu berumur 33 tahun, memiliki indeks masa tubuh 24. Kriteria eksklusif relawan yaitu tidak boleh mengonsumsi antibiotik selama \pm 6 bulan, tidak memiliki gangguan saluran pencernaan dan selama masa penelitian relawan tidak diizinkan mengonsumsi prebiotik atau probiotik. Selanjutnya relawan mengonsumsi empat macam pangan uji dalam periode yang terpisah. Takaran konsumsi masing-masing pangan uji didasarkan pada takaran sajian IIF sebesar $10 \mathrm{~g}$ dalam sampel. Takaran sajian masing-masing pangan uji yaitu sebagai berikut: buah naga merah segar $182,48 \mathrm{~g}$, selai buah naga merah $58,87 \mathrm{~g}$, buah naga putih segar $182,48 \mathrm{~g}$ dan selai buah naga putih $53,96 \mathrm{~g}$. Pelaksanaan uji setiap produk dilakukan dengan cara mengonsumsi pangan uji yang dilanjutkan dengan hari berikutnya dengan mengevaluasi profil mikroflora feses dan SCFA setelah 24 jam mengonsumsi produk uji. Selama masa pengujian, relawan mengonsumsi pangan non uji dari jenis yang sama. Setiap produk diuji dengan masa netralisasi relawan minimal 2 hari setelah menguji produk sebelumnya.

\section{Analisis profil mikroflora feses relawan manusia (Nurhayati et al., 2014 ${ }^{\mathrm{b}}$ ) \\ Sebanyak $0,1 \mathrm{~g}$ feses manusia sehat ditera dengan larutan garam fisiologis dan dihomogenkan dengan menggunakan vortex selama 10 detik.}


Feses diberi pengenceran untuk selanjutnya dilakukan pemupukan. Pengenceran dilakukan hingga $10^{-3}$ untuk media Salmonella Chromogenic Agar (Conda cat. 1122.1, Spain) dan media XLDA (Oxoid, CM0469, UK). Pengenceran dilakukan hingga $10^{-5}$ untuk media MRSA (Merck, VM 335160148, Germany). Pengenceran dilakukan hingga $10^{-6}$ untuk media NA (Merck, VMO35150904, Germany). Pemupukan dilakukan pada masing-masing cawan dengan media yang telah disiapkan dengan menggunakan teknik pemupukan bertingkat (overlay) untuk memberikan kondisi mikroaerofilik. Selanjutnya cawan petri diinkubasi dalam inkubator (Heraeus instrument D-63450 Hanau tipe B 6200, USA) pada suhu $37^{\circ} \mathrm{C}$ selama $24-48$ jam. Jumlah koloni yang tumbuh pada cawan dihitung berdasarkan metode Bacteriological Analytical Manual (BAM) (Jackson et al., 2001). Proses perhitungan total bakteri dilakukan dengan ketentuan sebagai berikut:

a. Cawan yang normal berisi 25-250 koloni. Semua koloni dihitung termasuk titik yang berukuran kecil. Pengenceran dan jumlah koloni semua dicatat untuk setiap cawan.

b. Cawan yang berisi lebih dari 250 koloni dicatat sebagai TBUD (terlalu banyak untuk dihitung). Jika tidak ada koloni yang tumbuh maka ditulis kurang dari 1 kali pengenceran terendah.

c. Rumus perhitungan yang digunakan adalah:

$$
N=\frac{\sum C}{\left[\left(1 \times n_{1}\right)+\left(0,1 \times n_{2}\right)\right] \times d}
$$

Keterangan:

$\mathrm{N}=$ Jumlah koloni

$\Sigma \mathrm{C}=$ Jumlah seluruh koloni yang dihitung

$\mathrm{n}_{1}=$ Jumlah cawan pada pengenceran 1

$\mathrm{n}_{2}=$ Jumlah cawan pada pengenceran 2

$\mathrm{d}=$ Tingkat pengenceran

Penentuan nilai indeks prebiotik (Manderson et al., 2005; Nurhayati, 2011; Nurhayati et al., 2014 ${ }^{\mathrm{b}}$ )

Pengaruh prebiotik terhadap pertumbuhan probiotik dinyatakan sebagai indeks prebiotik (IP) yang dihitung berdasarkan jumlah logaritmik pertumbuhan probiotik, terhadap mikroflora usus lainnya seperti jumlah bakteri Enterobactericeae termasuk E. coli dan Salmonella sp. Nilai IP ditentukan dengan cara menghitung log populasi probiotik dikurangi log populasi Enterobakteria yang selanjutnya dibagi dengan total mikroflora feses. Persamaan yang digunakan adalah sebagai berikut:

$$
\mathrm{IP}=\frac{\left(\log _{10} \text { probiotik }\right)_{t_{x}-t_{0}}\left(\log _{10} \text { bakteri Enterobactericea }\right)_{t_{x}-t_{0}}}{\left(\log _{10} \text { total mikroba }\right)_{t_{x}-t_{0}}}
$$

Keterangan: $t_{x}=$ waktu ke-24 jam; $t_{0}=$ waktu ke- 0 jam

\section{Analisis profil asam lemak rantai pendek Short Chain Fatty Acid (SCFA) feses relawan}

Analisis SCFA pada feses dilakukan dengan menggunakan metode yang dikembangkan oleh Laboratorium Balai Penelitian Ternak Badan Penelitian dan Pengembangan Pertanian Departemen Pertanian untuk analisis asam lemak volatil Volatile Fatty Acid (VFA) (Abdurachman dan Askar, 2000) yang sudah dimodifikasi untuk profil SCFA dari fermentasi oleh mikroflora manusia (Silva et al., 2008; Nurhayati, 2011). Sebanyak $1 \mathrm{~mL}$ cairan feses $(10 \% \mathrm{~b} / \mathrm{v})$ dimasukkan ke dalam tabung eppendorf dan ditambahkan 0,003 g asam sulfo 5-salisilat dihidrat (Merck, Jerman). Selanjutnya campuran disentrifus selama 10 menit pada $12000 \mathrm{rpm}$ suhu $7^{\circ} \mathrm{C}$. Supernatan diinjeksikan ke dalam kromatografi gas (Chrompack CP 9002 seri 946253, Belanda). Konsentrasi asam lemak rantai pendek dihitung berdasarkan luas peak sampel terhadap luas peak standar.

\section{Analisis data}

Nilai yang tertera pada hasil merupakan nilai rata-rata \pm standard deviasi. Data dianalisis dengan menggunakan dan uji $\mathrm{t}$ independent untuk menguji perbedaan komposisi kimia (kadar air, kadar pigmen $\beta$-sianin, kadar IIF, partikel terlarut, dan sifat-sifat prebiotik) antara buah naga segar dan selai. Tingkat kemaknaan yang digunakan adalah nilai $P<0,05$.

\section{HASIL DAN PEMBAHASAN}

\section{Kadar air selai buah naga}

Analisis kadar air dibutuhkan untuk melakukan konversi kadar IIF basis kering. Kadar air buah naga segar dan selainya berturut-turut yaitu $85,48 \%$ untuk buah naga merah segar, $84,99 \%$ untuk buah naga putih segar, 54,46\% untuk selai buah naga merah dan $57,69 \%$ untuk selai buah naga putih (Gambar 1).

Hasil uji $t$ menunjukkan bahwa proses pengolahan menjadi selai menyebabkan terjadinya pengurangan kadar air secara nyata dari kadar air buah naga segarnya yang diakibatkan adanya penguapan air selama pemanasan. Penguapan air dan proses pemanasan pada produk pangan semi basah Intermediet Moisture Food (IMF) dapat menyebabkan perubahan baik fisik kimia maupun fungsionalnya. Nurhayati et al. (2014 $)$ melaporkan bahwa terjadi perubahan sifat prebiotik yang lebih baik pada buah pisang mas masak yang digoreng vakum menjadi keripik pisang masak (ripe banana chip). Teknologi penggorengan vakum mampu mengurangi kadar air buah pisang mas masak hingga $85 \%$, sedangkan teknologi pemanasan puree buah naga menjadi selai mampu mengurangi kadar air hingga $35 \%$. 


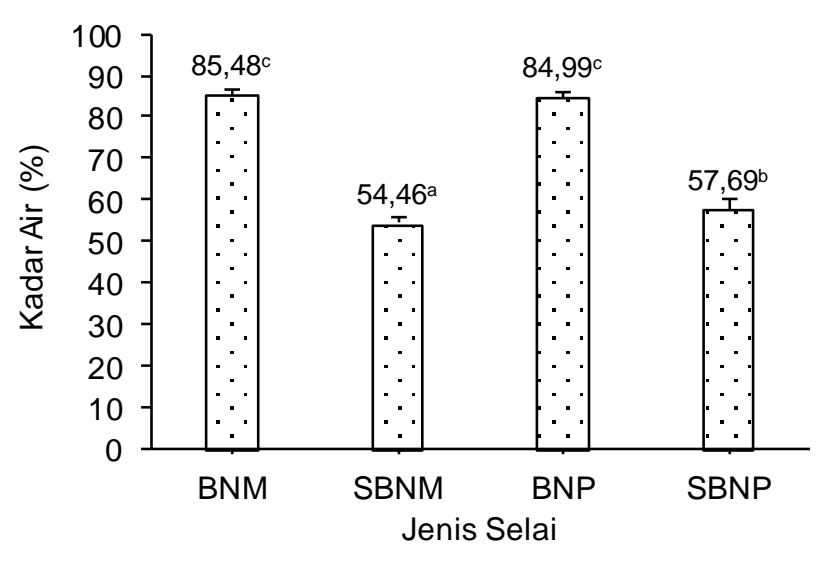

Gambar 1. Kadar air buah naga buah naga merah segar (BNM), buah naga putih segar (BNP), selai buah naga merah (SBNM), dan selai buah naga putih (SBNP). Angka-angka yang diikuti dengan huruf yang sama menunjukkan nilai berbeda tidak nyata pada taraf uji $\alpha \leq 0,05$

\section{Kadar pigmen $\beta$-sianin selai buah naga merah}

Hasil pengukuran kadar $\beta$-sianin berdasarkan nilai absorbansi pada panjang gelombang $550 \mathrm{~nm}$ menunjukkan bahwa pengolahan menjadi selai buah naga menyebabkan penurunan secara nyata nilai absorbansi kadar $\beta$-sianin (uji $t$ dengan tingkat kemaknaan $P<0,05)$ seperti yang terlihat pada Gambar 2. Hal ini mengindikasikan perlakuan pemanasan pada pengolahan buah naga merah segar menjadi selai menyebabkan penurunan kadar $\beta$ sianin.

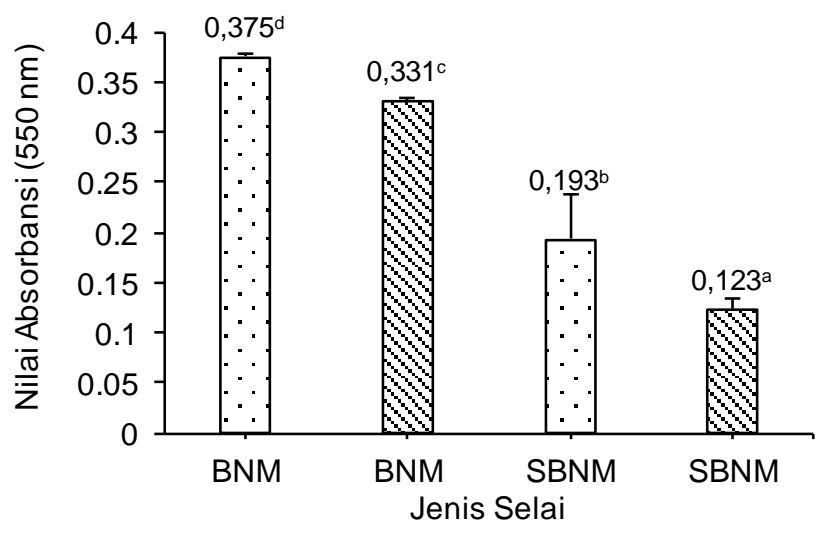

Gambar 2. Absorbansi pigmen $\beta$-sianin buah naga merah segar (BNM) dan selai buah naga merah (SBNM) dengan pelarut aquades ( $\square$ ) dan pelarut buffer fosfat ( $\mathrm{Q}$ ). Angka-angka yang diikuti dengan huruf yang sama menunjukkan nilai berbeda tidak nyata pada taraf uji $\alpha \leq$ 0,05

Penurunan nilai absorbansi yang mengindikasikan telah terjadinya penurunan kadar $\beta$ - sianin diduga akibat terjadi degradasi pigmen $\beta$ sianin oleh pemanasan. Menurut Devi et al. (2012) peningkatan suhu dapat mempercepat degradasi $\beta$ sianin berubah menjadi produk asam $\beta$-lamic dan cyclo-3,4-dihydroxyphenylalanine (cyclo-Dopa) yang bersifat tidak stabil. Selama pemanasan, $\beta$-sianin mengalami isomerasi, dekarboksilasi atau pemecahan ikatan sehingga menyebabkan perubahan warna dari merah hingga tampak coklat muda. Penurunan $\beta$-sianin akibat perlakuan suhu tinggi dapat memudarkan pigmen $\beta$-sianin pada buah Basella alba.

Beta-sianin merupakan anggota dari senyawa B-lain. Pigmen $B$-lain mengandung gugus aglikon dan glikon (berupa glukosa) yang dapat terhidrolisis dalam suasana asam pekat. Beta-lain merupakan pigmen yang dapat larut dalam pelarut polar seperti air dan metanol (Lestario et al., 2012). Oleh karena itu B-lain pada buah naga bisa cepat terdegradasi mengingat buah naga juga relatif lebih asam dan banyak mengandung air. Pietrzkowski et al. (2014) menjelaskan bahwa $B$-lain merupakan antioksidan kuat yang mampu menghambat aktivitas oksidasi mieloperoksida.

\section{Partikel terlarut selai buah naga putih}

Jumlah partikel terlarut sebanding dengan nilai absorbansi yang terukur. Semakin tinggi nilai absorbansi mengindikasikan semakin banyak partikel terlarut (larut air). Hasil uji $t$ pada tingkat kemaknaan $P<0,05$ menunjukkan jumlah partikel terlarut buah naga putih mengalami penurunan setelah diolah menjadi selai dari 0,546 menjadi 0,223 seperti yang ditunjukkan pada Gambar 3.

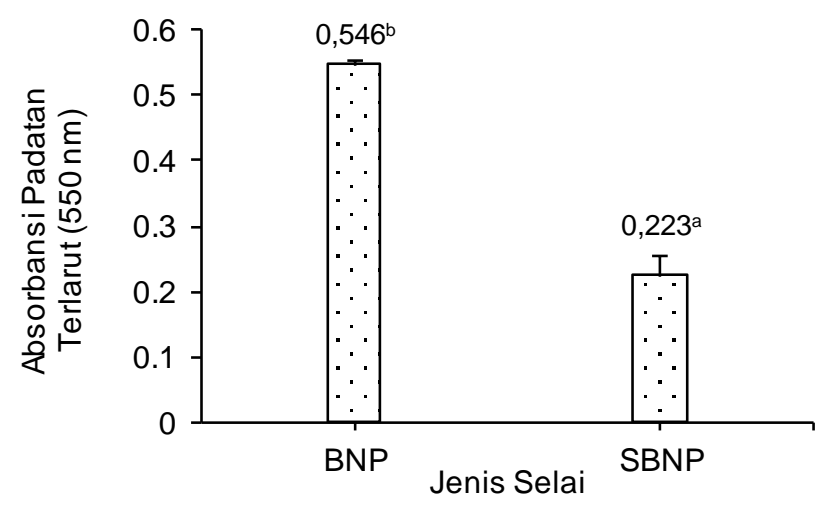

Gambar 3. Absorbansi padatan terlarut buah naga putih segar (BNP) dan selai buah naga putih (SBNP). Angka-angka yang diikuti dengan huruf yang sama menunjukkan nilai berbeda tidak nyata pada taraf uji $\alpha \leq 0,05$

Hal yang sama juga terjadi pada puree labu kuning yang mengalami proses evaporasi menjadi serbuk labu kuning. Adanya peningkatan suhu eva- 
porasi berpengaruh signifikan terhadap penurunan kelarutan serbuk labu kuning (Usmiati et al., 2005). Kelarutan suatu zat dalam air dapat berubah akibat pengolahan seperti perubahan kelarutan mineral. Beberapa faktor-faktor yang mempengaruhi ketersedian mineral terlarut antara lain interaksi mineral dengan mineral, interaksi vitamin dengan mineral dan interaksi serat dengan mineral.

\section{Kadar serat pangan tidak larut air (IIF) selai buah naga}

Hasil uji $t$ pada tingkat kemaknaan $P<0,05$ menunjukkan bahwa kadar IIF buah naga meningkat setelah diolah menjadi selai baik pada buah naga merah dan buah naga putih sebelum diolah (segar) maupun setelah diolah menjadi selai (Gambar 4). Kadar IIF buah naga merah segar sebesar 30,78\%, buah naga putih segar $29,27 \%$, selai buah naga merah sebesar $31,43 \%$, dan selai buah naga putih $30,85 \%$. Kadar IIF selai lebih tinggi daripada buah naga segar. Peningkatan kadar IIF pada selai diduga akibat terbentuknya komponen pangan kompleks sebagai produk reaksi karamelisasi, juga memungkinkan terjadinya reaksi maillard dengan adanya protein.

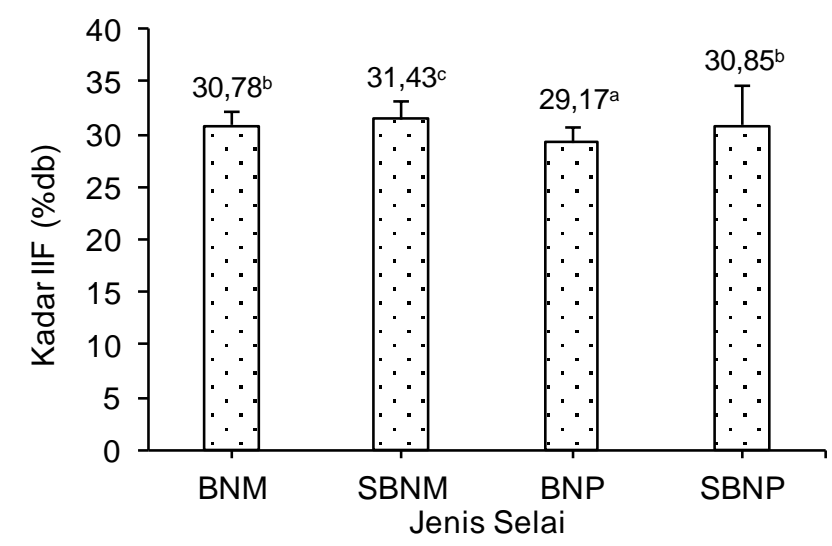

Gambar 4. Kadar IIF buah naga merah segar (BNM), buah naga putih segar (BNP), selai buah naga merah (SBNM), dan selai buah naga putih (SBNP). Angkaangka yang diikuti dengan huruf yang sama menunjukkan nilai berbeda tidak nyata pada taraf uji $\alpha \leq 0,05$

Buah naga merah dan putih mengandung gula pereduksi glukosa dan fruktosa (Wichienchot et al., 2010). Hal tersebut memperkuat dugaan bahwa selama proses pemasakan buah naga menjadi selai terjadi reaksi karamelisasi sehingga meningkatkan kadar serat pangan tidak larut air (IIF). Nurhayati et al. $\left(2014^{\mathrm{b}}\right)$ juga melaporkan bahwa kadar IIF pada pisang mas masak segar mengalami peningkatan setelah diberi perlakuan proses panas yaitu pengolahan menjadi keripik buah dengan teknologi peng- gorengan vakum dari $14,73 \%$ bk menjadi $48,49 \%$ bk. Dugaan terjadinya reaksi maillard didukung oleh laporan Tamanna dan Mahmood (2015). Dilaporkan bahwa pangan yang mengalami proses pengolahan seperti pemasakan pada suhu tinggi menyebabkan terjadinya reaksi kimia antara asam amino dengan gula reduksi membentuk produk reaksi Maillard Reaction Product (MRPs). Produk tersebut mampu menghambat pertumbuhan bakteri enterik. Selain itu bila menghasilkan akrilamid dapat bersifat karsinogen bagi manusia. Kedelai yang diproses menjadi flakes juga mengalami reaksi maillard.

Menurut Tensiska (2008) sejumlah senyawa alami maupun sintetik termasuk ke dalam definisi serat pangan seperti produk reaksi maillard, selulosa yang dimodifikasi (seperti CMC, produk hewani yang tidak dapat dicerna seperti kitin), oligosakarida (seperti inulin dan oligofruktosa). Semua senyawa tersebut menyumbangkan beberapa sifat sebagai serat pangan walaupun beberapa sifat yang lain berbeda dengan serat pangan. Ames (2009) melaporkan bahwa produk reaksi maillard berupa suatu polimer tidak tercerna sehingga dapat terhitung sebagai komponen yang tidak tercerna (IIF). Mengingat analisis IIF yang dilakukan adalah metode enzimatis yang dikombinasi dengan gravimetri yang memungkinkan terjadi bias perhitungan. Pushparaj dan Urooj (2011) menjelaskan bahwa perlakuan termal dengan perebusan, pemanasan bertekanan maupun penyangraian pada bahan pangan berpati mampu meningkatkan kadar serat pangan tidak larut air. Peningkatan tersebut disebabkan pembentukan kompleks antara serat dan protein yang tahan terhadap pemanasan dan dianggap sebagai serat pangan.

\section{Sifat-sifat prebiotik selai buah naga}

Nilai indeks prebiotik (IP) selai buah naga mengalami penurunan dibandingkan buah naga segar seperti yang ditunjukkan pada Gambar 5. Penurunan nilai IP terjadi pada relawan yang mengonsumsi selai baik dari selai buah naga merah maupun selai buah naga putih. Buah naga segar baik jenis merah maupun putih memiliki nilai IP yang tinggi $(1,18-1,7)$. Adanya pengolahan buah naga menjadi selai menurunkan nilai IP sekitar $50 \%(0,49$ 0,54). Terjadinya penurunan nilai IP mengindikasikan berkurangnya sifat-sifat prebiotik produk pangan tersebut. Penurunan nilai indeks prebiotik relawan yang mengonsumsi selai buah naga disebabkan pada feses relawan yang mengonsumsi selai, menunjukkan peningkatan populasi enterobakter sehingga populasinya lebih besar daripada populasi probiotik. Pengolahan selai diduga dapat menurunkan kemampuan prebiotik pada buah naga.

Prebiotik mampu meningkatkan komposisi mikroba yang menguntungkan dan meningkatkan aktivitasnya serta mengurangi mikroba yang merugi- 
kan pada mikroflora usus manusia (Antarini, 2011). Selain itu, prebiotik akan difermentasi secara mikrobiologis di dalam kolon menghasilkan asam lemak rantai pendek (SCFA) seperti asam asetat, asam propionat, asam butirat dan asam valerat. SCFA mampu memberi efek stimulasi selektif bagi pertumbuhan bakteri probiotik terutama bifidobakteria dan laktobasili (Date et al., 2014).

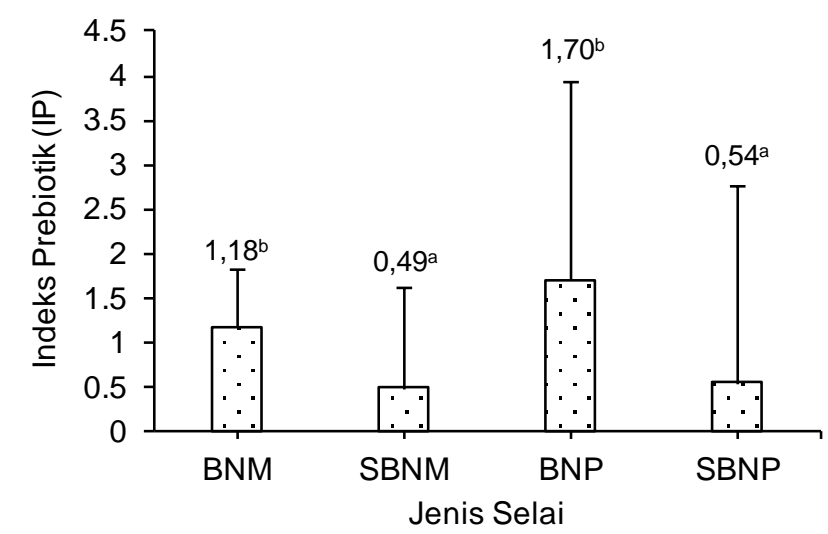

Gambar 5. Indeks prebiotik feses relawan yang mengonsumsi buah naga merah segar (BNM), selai buah naga merah (SBNM), buah naga putih segar (BNP), selai buah naga putih (SBNP). Angkaangka yang diikuti dengan huruf yang sama menunjukkan nilai berbeda tidak nyata pada taraf uji $\alpha \leq 0,05$

Penurunan kemampuan prebiotik dari selai buah naga diduga juga mengakibatkan penurunan konsentrasi asam propionat feses relawan yang mengonsumsi selai. Penurunan konsentrasi asam propionat feses relawan yang mengonsumsi selai seperti terlihat pada Tabel 1.

Tabel 1. Profil asam lemak rantai pendek feses relawan setelah mengonsumsi buah naga segar dan selainya

\begin{tabular}{lccc}
\hline \multirow{2}{*}{ Sampel } & \multicolumn{3}{c}{ Konsentrasi Asam Lemak Rantai } \\
& Asam & Asam & Asam \\
& Asetat & Propionat & Butirat \\
\hline Buah naga & $48,30 \pm$ & $8,70 \pm$ & - \\
merah segar & $0,05^{\mathrm{d}}$ & $0,04^{\mathrm{b}}$ & \\
(BNM) & & & \\
Selai buah naga & $7,48 \pm$ & $0,43 \pm$ & - \\
merah (SBNM) & $0,03^{\mathrm{a}}$ & $0,20^{\mathrm{a}}$ & \\
Buah naga putih & $8,97 \pm$ & $8,45 \pm$ & - \\
segar (BNP) & $0,07^{\mathrm{b}}$ & $0,09^{\mathrm{b}}$ & \\
Selai buah naga & $13,40 \pm$ & $0,67 \pm$ & - \\
putih (SBNP) & $0,01^{\mathrm{c}}$ & $0,01^{\mathrm{a}}$ & \\
\hline
\end{tabular}

Keterangan: Angka-angka pada kolom yang sama yang diikuti dengan huruf yang sama menunjukkan nilai berbeda tidak nyata pada taraf uji $\alpha \leq 0,05$
Sindt et al. (2004) melaporkan terjadinya penurunan asam lemak volatil feses (asam asetat, propionat dan butirat) pada sapi yang diberi pakan yang mengandung produk maillard. Keberadaan produk maillard diduga mengganggu metabolisme bakteri probiotik yang berakibat pada produksi SCFA. Produk reaksi maillard dapat bertindak sebagai antimikroba terhadap bakteri. Sifat antimikroba dari produk maillard disebabkan oleh keberadaan aminoreduktan dari produk reaksi maillard. Tamanna dan Mahmood (2015) melaporkan bahwa aminoreduktan MRP bersifat bakterisidal bagi Pseudomonas aeruginosa, Staphylococcus aureus. Kombinasinya dengan antibiotik mikacin, ciprofloxacin, imipenem, dan levofloxacin menunjukkan hasil yang efektif untuk melawan khamir. Al-Farabi (2013) menjelaskan bahwa produk reaksi maillard yaitu Advanced Glycation End-product (AGE) dalam sirkulasi dengan Receptor for Ad-vanced Glycation End-product (RAGE) akan meningkatkan produksi Reactive Oxygen Species (ROS) intraseluler dan up-regulation faktor transkripsi NF-kB dan produknya.

Asam asetat feses relawan yang mengonsumsi buah naga jenis merah bentuk segar lebih tinggi daripada mengonsumsi selainya. Akan tetapi asam asetat feses relawan yang mengonsumsi buah naga jenis putih akan lebih tinggi jika mengonsumsinya dalam bentuk selai. Hal ini diduga akibat adanya kemampuan E. coli yang juga menghasilkan metabolit asam asetat. Moons et al. (2004) melaporkan bahwa enteropatogenik $E$. coli selain mampu menurunkan $\mathrm{pH}$ juga dapat menghasilkan asam asetat. Hal ini yang menyebabkan konsentrasi asam asetat dari selai buah naga putih lebih tinggi daripada buah segarnya dan buah naga merah segar lebih tinggi daripada selainya. Nampak bahwa pengolahan buah naga menjadi selai mempengaruhi sifat fungsional seperti kemampuannya menghasilkan asam asetat setelah difermentasi mikroflora manusia.

\section{KESIMPULAN}

Pengolahan buah naga jenis merah maupun putih menjadi selai menyebabkan terjadinya penurunan kadar air hingga sekitar $40 \%$ dari buah segarnya, serta penurunan kadar $\beta$-sianin dan partikel terlarut. Kadar IIF selai meningkat sekitar $2 \%$ daripada kadar IIF buah naga segar. Populasi enterobakteria meningkat melebihi populasi bakteri probiotik. Penurunan konsentrasi asam propionat terjadi pada feses relawan yang mengonsumsi selai buah naga. Kenaikan konsentrasi asam asetat pada feses relawan tidak berbanding lurus dengan kenaikan nilai indeks prebiotik. Dengan demikian, untuk mendapatkan sifat fungsional prebiotik yang lebih baik disarankan mengonsumsi buah dalam bentuk segar. 


\section{UCAPAN TERIMAKASIH}

Penulis mengucapkan terima kasih kepada pihak yang telah membantu pelaksanaan penelitian ini. Terima kasih kepada DP2M DIKTI atas bantuan biaya penelitian melalui Program Penelitian Tahun 2014 dengan No. 0263/E5/2014.

\section{DAFTAR PUSTAKA}

Abdurachman, Askar S. 2000. Studi Banding Analisis VFA Total dengan Metode Destilasi dan Kromatografi Gas. Tema Teknis Fungsional non Penelitian. Laporan Balai Penelitian Ternak. Badan Penelitian dan Pengembangan Pertanian Departemen Pertanian Republik Indonesia.

Al-Farabi MJ. 2013. Antibodi terhadap advanced glycation end product, cara mutakhir pencegahan komplikasi diabetes melitus. J CDK-210. 40: 807-814.

Ames JM. 2009. Dietary maillard reaction products: implications for human health and disease. Czech J Food Sci 27: S66-S69.

Antarini AAN. 2011. Sinbiotik antara prebiotik dan probiotik. J IImu Gizi 2: 148-155.

[AOAC] Association of Official Agricultural Chemists. 2005. Official Methods of Analysis of AOAC International $18^{\text {th }}$ edition. Gaithersburg. USA.

Arie FM, Wignyanto, Mukhamad N. 2010. Studi pembuatan "puree" jambu biji merah (Psidium guajava L.) (kajian jenis dan konsentrasi penambahan filler (dekstrin dan tepung beras)). http://www.researchgate.net/profile/ariemulyadi/ publication. [12 November 2014].

Ariffin AA, Bakar J, Tan CP, Rahman RA, Karim R, Loi CC. 2009. Essential fatty acids of pitaya (dragon fruit) seed oil. Food Chem 114: 561564. DOI: 10.1016/j.foodchem.2008.09.108.

Charoensiri R, Kongkachuichai R, Suknicom S, Sungpuag P. 2009. Betacarotene, lycopene, and alpha-tocopherol contents of selected Thai fruits. Food Chem 113: 202-207. DOI: 10.1016/ j.foodchem.2008.07.074.

Date Y, Nakanishi Y, Fukuda S, Nuijima Y, Kato T, Umehara M, Ohno H, Kikuchi J. 2014. In vitro evaluation method for screening of candidate prebiotic foods. Food Chem 152: 251-260. DOI: 10.1016/j.foodchem.2013.11.126.

Desnilasari D, Lestari NPA. 2014. Formulasi minuman sinbiotik dengan penambahan puree pisang ambon (Musa paradisiaca var sapientum) dan inulin menggunakan inokulum Lactobacillus casei. Agritech 34: 257-265.
Devi PS, Reshmi SK, Aravindhan KM. 2012. The effect of light, temperature, $\mathrm{pH}$ on stability of $\beta$ cyanin pigments in Basella alba fruit. Asian J Pharm Clin Res 5: 107-110.

Gullon B, Gullon P, Sanz Y, Alonso JL, Parajó JC. 2011. Prebiotic potential of a refined product containing pectic oligosaccharides. LWT-Food Sci Technol 44: 1687-1696. DOI: 10.1016/j.Iwt. 2011.03.006.

Jackson JG, Merker RI, Blander R. 2001. Bacteriological Analytical Manual (BAM). 61-67. U.S. Food \& Drug Administration Center for Food Safety \& Applied Nutrition.

Rohin MAK, Bakar AA, Ali AM. 2014. Isolation and characterization of oligo-saccharides composition in organically grown red pitaya, white pitaya and papaya. Int $\mathrm{J}$ Pharm Pharmaceut Sci 6: 131-136.

Lestario NL, Petriana G, Martono Y. 2012. Pengaruh intensitas cahaya terhadap degradasi warna sirup yang diwarnai umbi bit merah (Beta vulgaris L. Var. rubra I.). Agric 25: 42-50.

Manderson K, Pinart M, Tuhoy KM, Grace WE, Hotchkiss AT, Widmer W, Yadhav MP, Gibson $\mathrm{R}$, Rastall RS. 2005. In vitro determination of prebiotic properties of oligo-saccharides derived from an orange juice manufacturing by-product stream. Appl Environ Microb 71: 8383-8389. DOI: 10.1128/ AEM.71.12.8383-8389.2005.

Mastuti R. 2010. Pigmen betalain pada famili amaranthaceae. http://biologi.ub.ac.id/files/20 10/12/BSS2010RM3.pdf. [15 Desember 2014].

Moons MMM, Schneeberger EE, Hecht GA. 2004. Enteropathogenic E. coli infection leads to appearance of aberrant tight junction strands in the lateral membrane of intestinal epithelial cells. Cell Microbiol 6: 783-793.

Nurhayati. 2011. Peningkatan Sifat Prebiotik Tepung Pisang dengan Indeks Glikemik Rendah melalui Fermentasi dan Siklus Pemanasan Pendinginan. [Disertasi]. Program Studi IImu Pangan. Bogor: Institut Pertanian Bogor.

Nurhayati, Kusuma G, Handayani N, Assadam A. 2014 ${ }^{\mathrm{a}}$. Karakteristik buah naga putih (Hylocereus undatus) dan buah naga merah (Hylocereus polyrhizus). Prosiding Seminar Nasional Optimalisasi Potensi Hayati untuk Mendukung Agroindustri Berkelanjutan. Universitas Trunojoyo. Bangkalan. 18 Juni 2014.

Nurhayati, Tamtarini, Jayus, Ruriani E, Hidayati LN. $2014^{\mathrm{b}}$. Prebiotic properties of ripe banana chip (RBC) Musa sinensis prepared by freezing and vacuum frying. Prosiding Seminar Nasional Nutrition and Halal Food. Universitas Negeri Surakarta. Solo. 25 April 2014. 
Pietrzkowski Z, Argumedo R, Shu C, Nemzer B, Wybraniec S, Reyes-Izquierdo T. 2014. Betalain-rich red beet concentrate improves reduced knee discomfort and joint function: a double blind, placebo-controlled pilot clinical study. Nutr Diet Sup 2014:6. DOI: 10.2147/ NDS.S59042.

Pushparaj FS, Urooj A. 2011. Influence of processing on dietary fiber, tannin and in vitro protein digestibility of pearl millet. Food Nutr Sci 2: 895-900. DOI: 10.4236/fns.2011.28122.

Silva ACC, Bastos DHM, Areas JAG. 2008. Volatile compounds in the thermoplastic extrusion of bovine rumen. Quim Nova 31: 1990-1993. DOI: 10.1590/S0100-40422008000800014.

Sindt JJ, Drouillard H, Thippareddi RK, Phebus CM, Coetzer KD, Kerr DL, Lambert TB, Farran SP, Montgomery, LaBrune HJ. 2004. Effect of Maillard reaction products on ruminal and fecal acid-resistant $E$. coli, total coliforms, VFA profiles, and $\mathrm{pH}$ in steers. J Anim Sci 82: 11701176.
Stintzing FC, Schieber A, Carle R. 2003. Evaluation of colour properties and chemical quality parameters of cactus juices. Eur Food Res Technol 216: 303-311. DOI: 10.1007/s00217002-0657-0.

Tamanna N, Mahmood N. 2015. Food processing and maillard reaction products: effect on human health and nutrition. Int J Food Sci 2015: 1-6. DOI: $10.1155 / 2015 / 526762$.

Tensiska. 2008. Serat Makanan. [Makalah]. Bandung: Jurusan Teknologi Industri Pangan Fakultas Teknologi Industri Pertanian, Universitas Padjadjaran.

Usmiati S, Setyaningsih D, Purwani EY, Yuliani S, Maria OG. 2005. Karakteristik Serbuk Labu Kuning (Cucurbita moschata). J Teknol Industri Pangan 16: 157-167

Wichienchot S, Jatupornpipat M, Rastall RA. 2010. Oligosaccharides of pitaya (dragon fruit) flesh and their prebiotic properties. Food Chem 120: 850-857. DOI: 10.1016/j.foodchem.2009.11.02 6. 